\title{
BioéthiqueOnline
}

\section{Judging Culpability in Dwyer's Climate Change "Gaia Commission”: A Response to Dwyer}

\section{Sean A. Valles}

Volume 4, 2015

Reçu : 19 Aug 2015; publié : 18 Sept 2015; éditeurs : Charl Els, Aliya Affdal \& Maude Laliberté; oeuvre discutée: J Dwyer. The Gaia Commission: Climate Change and Moral

ResponsibilityBioéthiqueOnline 2014, 3/18

URI : https://id.erudit.org/iderudit/1035509ar

DOI : https://doi.org/10.7202/1035509ar

Aller au sommaire du numéro

Éditeur(s)

BioéthiqueOnline

ISSN

1923-2799 (numérique)

Découvrir la revue

Citer cet article

Valles, S. A. (2015). Judging Culpability in Dwyer's Climate Change "Gaia

Commission”: A Response to Dwyer. BioéthiqueOnline, 4.

https://doi.org/10.7202/1035509ar
Résumé de l'article

Ce commentaire examine les concepts " d'imprudence, de négligence et d'indifférence " dans la courte histoire de James Dwyer, « La Commission Gaia : le changement climatique et la responsabilité morale». 


\title{
Judging Culpability in Dwyer's Climate Change "Gaia Commission": A Response to Dwyer
}

\author{
COMMENTAIRE / COMMENTARY \\ Sean A. Valles ${ }^{1}$
}

Reçu/Received: 19 Aug 2015

Publié/Published: 18 Sept 2015

Éditeurs/Editors: Charl Els, Aliya Affdal \& Maude Laliberté

Oeuvre discutée/Work discussed: J Dwyer. The Gaia Commission: Climate Change and Moral Responsibility

BioéthiqueOnline 2014, 3/18

2015 SA Valles, Creative Commons Attribution 4.0 International License

\section{Résumé}

Ce commentaire examine les concepts « d'imprudence, de négligence et d'indifférence » dans la courte histoire de James Dwyer, "La Commission Gaia : le changement climatique et la responsabilité morale ».

\section{Mots clés}

bioéthique, changements climatiques, éthique environnementale, culpabilité, justice intergénérationnelle

\section{Summary}

This commentary examines the concepts "recklessness, negligence and indifference" in James Dwyer's short story, "The Gaia Commission: Climate Change and Moral Responsibility."

\section{Keywords}

bioethics, climate change, climate ethics, culpability, intergenerational justice

Affiliations des auteurs / Author Affiliations

${ }^{1}$ Lyman Briggs College and Department of Philosophy, Michigan State University, East Lansing, USA

\section{Correspondance / Correspondence}

Sean A. Valles, valles@msu.edu

Conflit d'intérêts

Aucun déclaré

\section{Conflicts of Interest}

None declared

James Dwyer's short story, "The Gaia Commission: Climate Change and Moral Responsibility," [1] is a valuable and provocative contribution to the dialogue about the bioethics of climate change. We have each written papers asking our bioethics colleagues to pay more attention to climate change [2,3]. By authoring a short story, Dwyer is continuing that same effort using another format, science fiction. This is a creative move, though not an unprecedented one. Historians Naomi Oreskes and Erik Conway gained fame for their non-fiction analysis of climate change denialism in Merchants of Doubt [4], and then followed the project with The Collapse of Western Civilization [5], a science fiction history of human responses to climate change, written from the year 2393. Like Oreskes and Conway's book, Dwyer's text speculates how our descendants will think of us, drawing attention to the ethical problem of intergenerational justice (as articulated by climate ethicists such as Stephen Gardiner) [6]. The ethics of our responses to climate change are inseparable from the fact that the harms and benefits will be distributed across many future generations.

Dwyer's imagined Gaia Commission raises many ethical questions, including the intriguing: what does the Gaia Commission teach us about the nature of individuals' responsibility for contributing to climate change? Yet, the text leaves much unsaid about how the Gaia Commission evaluates guilt. Its charges, like US criminal charges, appear to take into account not only defendants' carbon footprints (their actions), but also mens rea (defendants' mental states). In the story, "the charges were always the same: recklessness, negligence, and indifference," all of which are concepts that posit a blameworthy mental state in defendants. Yet, the only relevant evidence for judging guilt in the Gaia court appears to be emissions-related behaviour (usage of heating energy, etc.), with all other evidence treated as secondary "mitigating factors" of some sort ("The emissions don't lie. I'm just looking for mitigating factors that the Commission will recognize."). So, how much does the mindset of the polluter matter when the Gaia Commission renders its judgment? 
The prospect of charging defendants with the specific crime of climate change indifference is timely in the 2010s, when small-scale "green" habits are in vogue (e.g., avoiding disposable utensils like Francis, the fictional defendant) while there is little public will to radically reduce global emissions. I heartily agree with Dwyer that indifference is a central matter of concern in climate change bioethics, having myself published on that topic [3]. Dwyer's further step of imagining actual penalties for such indifference raises many unanswered questions about the justice system in this imagined future.

In the Model Penal Code, the template now used (to varying extents) in many US states, negligence and recklessness are distinct types of culpable states of mind, with correspondingly different punishments when one acts with such a state of mind. A reckless actor is aware that his or her action has some risk of causing harm - not knowing for sure - but does the action anyway. By contrast, a negligent actor is not aware that his or her action has some risk of causing harm, but he or she should have been aware of that risk. As Simons summarizes, in the Model Penal Code's hierarchy of culpability, "all else being equal, purpose is more culpable than knowledge, which is more culpable than recklessness, which is more culpable than negligence" [7]. Recklessness, negligence and indifference are now considered distinct in morally and legally significant ways, so it is quite interesting to see that Dwyer's imagined climate change commission interprets these concepts differently.

Francis' (the defendant's) proposal for his own punishment suggests that Dwyer is most troubled by reckless or knowing behaviour, rather than negligent behaviour: "I should be made to figure out why so many well-informed people failed to act appropriately." That is, Dwyer aims his sharpest criticism at those who do indeed know better than to continue their wasteful lifestyles. Yet, the narrator also mentions the "business people who sowed doubts." So, are sincere climate sceptics negligent when they generate carbon emissions needlessly? They genuinely don't know better, but should they? Surely some bioethicists are knowingly causing climate harms, while others are largely ignorant of how their behaviours contribute to climate change.

There is a great deal of ambiguity in Dwyer's text, but ambiguity of a welcome sort: it inspires the reader to continue pondering the text long after the reading is over. Dwyer tells us that the story "shows where we might end up if we do not change our present course." He declines to clarify which aspects of the Gaia Commission he endorses, even in the brief preamble pleading with his bioethics peers to engage with the pressing contemporary problem of climate change. Leaving this unsaid actually makes the text more engaging. Stepping outside of the usual ethics paper format, Dwyer shows that there are valuable ethical insights to be gleaned through the process of imagining how future generations will judge our responsibility for our contributions to causing climate change.

\section{List of References}

1. Dwyer J. The Gaia Commission: Climate Change and Moral Responsibility BioéthiqueOnline. $2014 ; 3 / 18$.

2. Dwyer J. How to Connect Bioethics and Environmental Ethics: Health, Sustainability, and Justice. Bioethics. 2009; 23: 497-502.

3. Valles SA. Bioethics and the Framing of Climate Change's Health Risks. Bioethics. 2015; 29: 334-41.

4. Oreskes $\mathrm{N}$ and Conway EM. Merchants of Doubt: How a Handful of Scientists Obscured the Truth on Issues from Tobacco Smoke to Global Warming. New York: Bloomsbury Publishing, 2010.

5. Oreskes $\mathrm{N}$ and Conway EM. The Collapse of Western Civilization: A View from the Future. New York: Columbia University Press, 2014.

6. Gardiner SM. A Call for a Global Constitutional Convention Focused on Future Generations. Ethics \& International Affairs. 2014; 28: 299-315.

7. Simons KW. Should the Model Penal Code's Mens Rea Provisions Be Amended. Ohio State Journal of Criminal Law. 2003; 1: 179-205. 